\title{
Water quality assessment using NSFWQI, OIP and multivariate techniques of Ganga River system, Uttarakhand, India
}

\author{
Gagan Matta ${ }^{1}$ (D) $\cdot$ Anjali Nayak ${ }^{1} \cdot$ Avinash Kumar $^{1} \cdot$ Pawan Kumar $^{1}$
}

Received: 9 March 2020 / Accepted: 28 July 2020 / Published online: 14 August 2020

(c) The Author(s) 2020

\begin{abstract}
Ganga River water is very much stressed with the rapidly increasing population, climate change and water pollution that increase domestic, agricultural and industrial needs. This study assesses the surface water quality of the River Ganga in India, using NSFWQI, OIP and multivariate techniques. During the current study, water samples from Ganga River were collected for the assessment of 19 physico-chemical determinants from 20 sampling locations. Water quality indices (WQIs) is used to classify the overall impact of different variables of water. Multivariate techniques were utilized to assess the water conditions for productive management of fresh water quality. The WQI results showed that surface water quality varied at the selected sampling sites among medium and good categories. The PCA generates the 6 principle components which highly contributes $(80.3 \%)$ in influencing the hydro-chemistry of river water. Agricultural waste runoff, untreated effluents and many other anthropogenic activities were identified as main contributor in decreasing the water quality of the River Ganga. To maintain and protect this fresh water resources against contamination, the usage of stringent policies and rules are expected to preserve fresh water resources for people in the future.
\end{abstract}

Keywords River Ganga $\cdot$ Physico-chemical parameters $\cdot$ NSFWQI $\cdot$ OIP $\cdot$ PCA $\cdot$ Multivariate statistical methods

\section{Introduction}

Rivers are one of the significant resources of freshwater to the people for the use in many purposes. India with $18 \%$ of world's population and $4 \%$ of world's water resources availability, is a water stressed nation with $1588 \mathrm{~m}^{3}$ per capita per annum water supply. The Uttarakhand is water rich state of the country with $21 \%$ availability of surface water against inevitably increase in agriculture, industrial and domestic water needs (TERI 2017; Census of India 2011).

The importance of Ganga River is not only for its sociocultural perspective, but also for various livelihood and economic activities for the people living around the basin. The improvement in the river health is growing debate in India since last decade, mainly in terms of its quality and quantity (Matta and Uniyal 2017). The river is facing multi-dimensional issues like, flow disturbance, water pollution, climate

Gagan Matta

drgaganmatta@gkv.ac.in

1 Hydrological Research Lab., Department of Zoology and Environmental Science, Gurukula Kangri

Vishwavidyalaya, Haridwar, India influences, habitat and biodiversity conservation (Kaushal et al. 2019). The water pollution has become a global threat for developing countries due to the climate change, rapid urbanization, agricultural runoff and industrialization (Bhardwaj 2005; Matta et al. 2018c; Rana et al. 2017).

It is astute to save and control the surface water from pollution and to have solid data on surface water quality for viable management. In this way, regular assessment of the surface water quality is required to maintain and control the surface water from degradation (Barakat et al. 2016; Shukla et al. 2017b; Matta et al. 2015). For that purpose, water quality indices (WQIs) are the mathematical expressions to evaluate the water quality by process the dataset of different variables into simple numeric quality rating scales. (Abbasi and Abbasi 2012). WQIs are globally accepted approach to assess the water quality and each WQI uses a different set of variables (Bharti and Katyal 2011). It is used as communication tool for policy makers, researchers and different governmental bodies to report the health of water body to public in a reliable way (Sadiq et al. 2010). The WQIs uses different selection process, statistical transformation, weighing of parameters and interpretation of final numeric values (Lumb et al. 2011; Alobaidy et al. 2010). Many of the 
research work has been used various WQIs for the assessment and monitoring of different surface water quality (Shah and Joshi 2017; Matta et al. 2018a; Son et al. 2020; Matta et al. 2020).

Multivariate methods such cluster analysis (CA) and principle component analysis (PCA) are utilized in different studies to recognize potential pollutants (Fan et al. 2010; Massoud 2012; Misaghi et al. 2017). PCA is a multivariate technique, and in the situations where colossal measure of information is accessible, it is a reasonable way to diminish the data (Noori et al. 2009, 2010). Moreover, CA is additionally one of the multivariate techniques used to evaluate relative similarity in the homogeneity of estimated parameters (Shrestha and Kazama 2007).

The goal of this study is to evaluating the physico-chemical properties of the river water and provide appropriate picture of present water quality of the River Ganga, through NSFWQI, OIP model and other environmetric techniques like PCA, CA so as to facilitate emerging issues.

\section{Materials and methods}

\section{Description of research area}

The River Ganga basin cover four nations (India, China, Bangladesh and Nepal), spreads on land surface of about $1,080,000 \mathrm{Km}^{2}$, of which $80 \%$ lies within India (Tare et al. 2015). About $43 \%$ of total inhabitants of India live along the River Ganga basin (Tare et al. 2013) and utilize river water directly or indirectly for various purposes. River Ganga with total run of approximately $2525 \mathrm{~km}$ long, is a mountainous river originates from Gangotri glacier of northern Himalayan region as 'Bhagirathi River' (known as one of major headwater stream) (NMCG 2019). The river name Ganga came to known where two head-stream (Bhagirathi and Alaknanda) confluence at Devprayag (Chakrapani and Saini 2009; Matta et al. 2018b).

The climatic condition of study area is subtropical to temperate with three seasons summer, monsoon and winter (Chauhan 2010). The research area lies between the coordinates from $30049^{\prime} \mathrm{N}$ and $79010^{\prime} \mathrm{E}$ to $29051^{\prime} \mathrm{N}$ and 77053' E. The state also has fully disparity between its hilly districts to plains and characterized by climatic variation from freezing cold (snow cover up to 10 feet from land surface) at upstream site to very warm condition (up to 450C during summer season) at downstream stations (CWC 2012). The most rainfall occurs in monsoon season (June-September) with an average annual rainfall range from $350 \mathrm{~mm}$ in west to $2500 \mathrm{~mm}$ in east of Ganga River Basin (Kumar et al. 2019).

The sediment and water flux of Ganga River system annually supplies 400-500 Million tonne (Mt.) and $380 \mathrm{~km}^{3}$, respectively, to Bay of Bengal (Awasthi et al. 2018; Lupker et al. 2012). The river bed consists of boulders, rocks and cobbles, whereas water status is ultra-oligotrophic to oligotrophic in nature (Mathur and Kapoor 2015).

The sampling locations were selected on the basis of land use pattern, population, potential anthropogenic activities and socio-economic important of locations. The description of selected monitoring locations is given in Table 1 and study area map is shown in Fig. 1.

\section{Sample collection and analysis}

A total of 120 water samples were collected from 20 monitoring locations during winter: November-February, summer: March-June, monsoon: July-August and post-monsoon season September-October, for the year 2015-2016. The samples were gathered bimonthly, from $15 \mathrm{~cm}$ depth of superficial layer in triplicate manner at each site, in a preacid washed polypropylene Nalgene Wide-Mouth Natural HDPE bottles of $1000 \mathrm{ml}$. The samples were stored in ice bucket by maintaining its temperature up to $4{ }^{\circ} \mathrm{C}$, transported to laboratory and refrigerated to avoid any contamination and the effect of temperature and light.

In-situ observations were done for few physico-chemical parameters, i.e., 1. light intensity (LI), 2. temperature, 3. conductivity, 4. water velocity, 5 . total dissolved solids (TDS), and 6. dissolved oxygen (DO). The LI and water velocity was measured by digital lux meter and water velocity meter, whereas a pre-calibrated Portable Multi-Parameter, Model-TMULTI 27 (TOSHCON), was used for on-site observations. The remaining parameters: 7. turbidity, 8. total solids (TS), 9. total suspended solids (TSS), 10. biochemical oxygen demand (BOD), 11. chemical oxygen demand (COD), 12. free $\mathrm{CO}_{2}$, 13. alkalinity, 14. hardness, 15. acidity, 16. chloride $\left(\mathrm{Cl}^{-}\right), 17$. total phosphate $(\mathrm{P}), 18$. total kjeldahl nitrogen (TKN) and 19. sulfate $\left(\mathrm{SO}_{4}^{-}\right)$were determined in the laboratory by standard protocol proposed by American Public Health Association (APHA) (2012). Turbidity (TU) was also recorded in the laboratory by digital meter (model: 5Dim). Total phosphate and $\mathrm{SO}_{4}^{-}$were measured with the applicability of UV spectrophotometer Cary 60. Distilled, deionized water of Perkins was used for all electrode and glassware wash, dilutions and aqueous analysis.

\section{National sanitation foundation water quality index (NSFWQI)}

This mathematical expression provides a uniform and meaningful method for assessing the overall quality of freshwater. In this method, a total of 9 parameters were assigned and calculation is expressed as following equation: (1): 
Table 1 Description of Sampling Sites with their geo-coordinates

\begin{tabular}{|c|c|c|c|c|c|c|}
\hline $\begin{array}{l}\text { Sampling site } \\
\text { no.(m) }\end{array}$ & Site codes & Sampling site & Type of system & Latitude & Longitude & Elevation \\
\hline 1. & S1 & Gangotri & River system & $30^{\circ} 49^{\prime} 59.99^{\prime \prime} \mathrm{N}$ & $79^{\circ} 10^{\prime} 0.00^{\prime \prime} \mathrm{E}$ & 3065 \\
\hline 2. & $\mathrm{~S} 2$ & Uttarkashi & River system & $30^{\circ} 43^{\prime} 48.00^{\prime \prime} \mathrm{N}$ & $78^{\circ} 27^{\prime} 0.00^{\prime \prime} \mathrm{E}$ & 1127 \\
\hline 3. & S3 & Badrinath & River system & $30^{\circ} 43^{\prime} 48.00^{\prime \prime} \mathrm{N}$ & $79^{\circ} 28^{\prime} 48.00^{\prime \prime} \mathrm{E}$ & 3116 \\
\hline 4. & S4 & Tehri Dam & River system & $30^{\circ} 22^{\prime} 23.99^{\prime \prime} \mathrm{N}$ & $78^{\circ} 28^{\prime} 29.99^{\prime \prime} \mathrm{E}$ & 705 \\
\hline 5. & S5 & Koteshwar & River system & $30^{\circ} 15^{\prime} 36.37^{\prime \prime} \mathrm{N}$ & $78^{\circ} 29^{\prime} 53.61^{\prime \prime} \mathrm{E}$ & 572 \\
\hline 6. & S6 & Rudraprayag & River system & $30^{\circ} 17^{\prime} 16.57^{\prime \prime} \mathrm{N}$ & $78^{\circ} 58^{\prime} 45.11^{\prime \prime} \mathrm{E}$ & 617 \\
\hline 7. & S7 & Srinagar & River system & $30^{\circ} 13^{\prime} 17.03^{\prime \prime} \mathrm{N}$ & $78^{\circ} 46^{\prime} 48.16^{\prime \prime} \mathrm{E}$ & 553 \\
\hline 8. & S8 & Devprayag & River system & $30^{\circ} 8^{\prime} 46.12^{\prime \prime} \mathrm{N}$ & $78^{\circ} 35^{\prime} 54.91^{\prime \prime} \mathrm{E}$ & 463 \\
\hline 9. & S9 & Byasi, Rishikesh & River system & $30^{\circ} 3^{\prime} 53.50^{\prime \prime} \mathrm{N}$ & $78^{\circ} 28^{\prime} 21.44^{\prime \prime} \mathrm{E}$ & 412 \\
\hline 10. & $\mathrm{~S} 10$ & LakshmanZhoola, Rishikesh & River system & $30^{\circ} 7^{\prime} 34.79^{\prime \prime} \mathrm{N}$ & $78^{\circ} 19^{\prime} 46.85^{\prime \prime} \mathrm{E}$ & 360 \\
\hline 11. & S11 & TriveniGhat, Rishikesh & River system & $30^{\circ} 6^{\prime} 10.90^{\prime \prime} \mathrm{N}$ & $78^{\circ} 17^{\prime} 55.00^{\prime \prime} \mathrm{E}$ & 339 \\
\hline 12. & $\mathrm{~S} 12$ & Pashulok Barrage, Rishikesh & River system & $30^{\circ} 4^{\prime} 29.84^{\prime \prime} \mathrm{N}$ & $78^{\circ} 17^{\prime} 14.65^{\prime \prime} \mathrm{E}$ & 335 \\
\hline 13. & S13 & Chilla Power House, Rishikesh & River system & $29^{\circ} 58^{\prime} 36.35^{\prime \prime} \mathrm{N}$ & $78^{\circ} 12^{\prime} 8.04^{\prime \prime} \mathrm{E}$ & 306 \\
\hline 14. & S14 & Bhimgoda Barrage, Haridwar & River/Canal system & $29^{\circ} 57^{\prime} 23.30^{\prime \prime} \mathrm{N}$ & $78^{\circ} 10^{\prime} 58.27^{\prime \prime} \mathrm{E}$ & 289 \\
\hline 15. & $\mathrm{~S} 15$ & Har-Ki-Pauri, Haridwar & Canal system & $29^{\circ} 57^{\prime} 18.83^{\prime \prime} \mathrm{N}$ & $78^{\circ} 10^{\prime} 14.46^{\prime \prime} \mathrm{E}$ & 293 \\
\hline 16. & S16 & Mayapur, Haridwar & Canal system & $29^{\circ} 56^{\prime} 31.55^{\prime \prime} \mathrm{N}$ & $78^{\circ} 9^{\prime} 20.65^{\prime \prime} \mathrm{E}$ & 282 \\
\hline 17. & S17 & Jatwara Bridge, Haridwar & Canal system & $29^{\circ} 55^{\prime} 9.74^{\prime \prime} \mathrm{N}$ & $78^{\circ} 6^{\prime} 12.83^{\prime \prime} \mathrm{E}$ & 284 \\
\hline 18. & S18 & Missarpur Village, Haridwar & River system & $29^{\circ} 53^{\prime} 42.60^{\prime \prime} \mathrm{N}$ & $78^{\circ} 8^{\prime} 46.92^{\prime \prime} \mathrm{E}$ & 265 \\
\hline 19. & S19 & Bahadrabad, Haridwar & Canal system & $29^{\circ} 55^{\prime} 11.72^{\prime \prime} \mathrm{N}$ & $78^{\circ} 2^{\prime} 26.47^{\prime \prime} \mathrm{E}$ & 278 \\
\hline 20. & S20 & Roorkee & Canal system & $29^{\circ} 51^{\prime} 23.89^{\prime \prime} \mathrm{N}$ & $77^{\circ} 53^{\prime} 0.43^{\prime \prime} \mathrm{E}$ & 267 \\
\hline
\end{tabular}
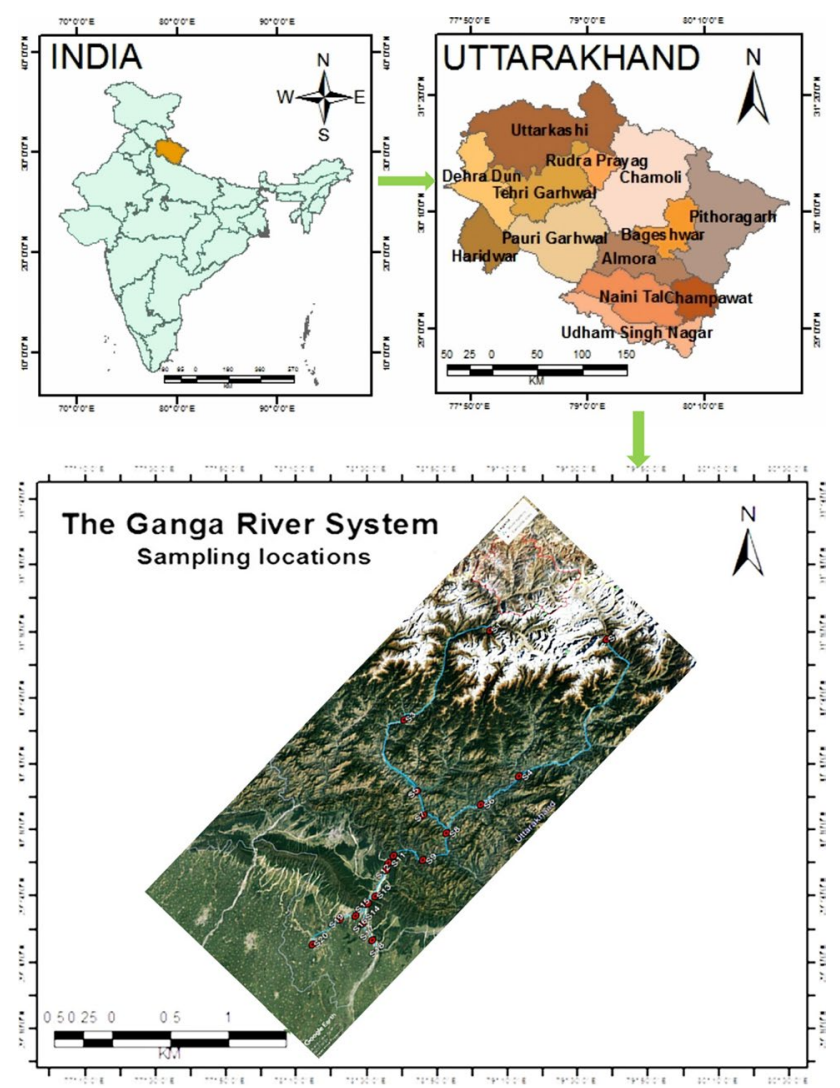

Fig. 1 Location map of the study area showing monitoring station of Ganga River system
$N S F W Q I=\sum_{i=1}^{n} w_{i} q_{i}$

where $q_{i}$ represents the assigned curve based sub-index value for ith variable which is ranged from 0 to $100, w_{i}$ is the weighting coefficient for ith parameter with range from 0 to 1, and described in Eq. (2),

$\sum_{i=1}^{n} w_{i}=1$

$n$ is the number of total variables considered, the NSFWQI rating scale is also divided in five quality classes and considered as very bad (0-25), bad (25-50), medium (50-75), good (70-90) and excellent (90-100) (Brown et al. 1970).

\section{Overall index of pollution (OIP)}

The OIP was proposed by Sargaonkar and Deshpande (2003) for the assessment of surface water quality, specifically under Indian condition. The calculation of OIP was performed by considering turbidity, TDS, BOD, hardness, chloride and sulfate concentrations of water samples. The observed concentrations were put into assigned mathematical expressions for individual parameter, given 
in Table 2 to find pollution index score $\left(P_{i}\right)$. The final OIP value was estimated by following Eq. (3):

$O I P=\frac{1}{n} \sum_{i=1}^{n} P_{i}$

where, $P i=$ pollution index value for the $i$ th parameter, $n=$ number of parameters.

The final numeric index score was used to classify water quality into different pollution classes given in Table 3.

\section{Multivariate techniques}

The multivariate technique like principle component analysis (PCA) was analyzed with the support of Kaiser-Meyer-Olkin (KMO) and Bartlett tests. To recover the association among data sources and essential factors similarly as to accomplish better goals, the Varimax technique was used (Noori et al. 2010; Ouyang 2005). To observe cluster analysis (CA), averages of nineteen parameters for 20 sampling sites were evaluated. The comparability among groups and isolating similar clusters were resolved dependent on Euclidean distance. In the present study, hierarchical CA was executed for a set of standardized statistics with Ward's Method.

Table 2 Mathematical expressions for value function curves (Sargoankar and Deshpande 2003)

\begin{tabular}{llcl}
\hline Sr. no. & Parameter & $\begin{array}{l}\text { Concentra- } \\
\text { tion range }\end{array}$ & Mathematical expressions \\
\hline 1. & Turbidity & $10-500$ & $x=(y+43.9) / 34.5$ \\
2. & TDS & $<500$ & $x=1$ \\
3. & BOD & $2-30$ & $x=y / 1.5$ \\
4. & Hardness & $75-500$ & $x=\exp (y+42.5) / 205.58$ \\
5. & $\mathrm{Cl}^{-}$ & $<150$ & $x=1$ \\
6. & $\mathrm{SO}_{4}^{-}$ & $<150$ & $x=1$ \\
\hline
\end{tabular}

\section{Results and discussion}

\section{Seasonal variation in physico-chemical parameters of Ganga River water}

The observed analytical ranges of different parameters of water testing are represented in Table 4. Water and light are two important components required for the development and growth of aquatic plants (Hazrati et al. 2016), which makes essential to measure the intensity of light in any freshwater resources. The highest average value of LI was recorded during summer season $\left(2674.1 \pm 1172.18 \mu \mathrm{mol} \mathrm{m} \mathrm{m}^{-2} \mathrm{~s}^{-1}\right.$ ), whereas lowest value was observed during winter season $\left(1932.81 \pm 671.78 \mu \mathrm{mol} \mathrm{m} \mathrm{m}^{-2} \mathrm{~s}^{-1}\right)$. The temperature is an important parameter for aquatic environment. The seasonal average temperature of the river water was recorded $16.40 \pm 3.0,16.62 \pm 3.8,17.02 \pm 3.7$ and $16.03 \pm 3.7 \mathrm{C}$ during winter, summer, monsoon and post-monsoon season, respectively. The mean variation in conductivity is noticed as $138.15 \pm 28.41,132.27 \pm 27.58,140.56 \pm 39.67$ and $131.15 \pm 42.06 \mu \mathrm{S} / \mathrm{cm}^{2}$ during winter, summer, monsoon and post-monsoon season, respectively.

TU values were recorded higher than permissible limit (5 NTU) for drinking water proposed by BIS (2012) throughout the study period. The average value of turbidity varied from $109.43 \pm 105.32,132.91 \pm 129.50$, $107.68 \pm 110.03$ and $106.29 \pm 110.47$ NTU for winter, summer, monsoon and post-monsoon season, respectively. The mean observation of water velocity varied from $0.91 \pm 0.32,1.06 \pm 0.36,1.00 \pm 0.34$ and $1.13 \pm 18.56 \mathrm{~m} / \mathrm{s}$ during winter, summer, monsoon and post-monsoon season, respectively. Total solids are residues, that left after evaporation and drying of the unfiltered sample. The average total solid at all seasons was recorded $319.93 \pm 373.74,350.68 \pm 334.01,371.21 \pm 296.07$ and $468.37 \pm 396.35 \mathrm{mg} / \mathrm{L}$ for winter, summer, monsoon and post-monsoon season, respectively. The average amount of total dissolved solid was observed, 50.02 \pm 59.80 , $67.68 \pm 62.73,54.02 \pm 40.59$ and $89.78 \pm 86.16 \mathrm{mg} / \mathrm{L}$ during winter, summer, monsoon and post-monsoon

Table 3 Water quality classification in the overall index of pollution (Sargoankar and Deshpande 2003)

\begin{tabular}{|c|c|c|c|c|c|c|c|c|}
\hline \multirow[t]{2}{*}{ Classification } & \multirow[t]{2}{*}{ Class } & \multirow{2}{*}{$\begin{array}{l}\text { Class } \\
\text { index } \\
\text { score }\end{array}$} & \multicolumn{6}{|c|}{ Concentration limit/ranges of water quality parameters } \\
\hline & & & Turbidity NTU & $\operatorname{TDS}\left(\mathrm{mg} \mathrm{L}^{-1}\right)$ & $\mathrm{BOD}\left(\mathrm{mg} \mathrm{L}^{-1}\right)$ & $\begin{array}{l}\text { Hardness } \\
\left(\mathrm{mg} \mathrm{L}^{-1}\right)\end{array}$ & $\begin{array}{l}\text { Chlorine } \\
\left(\mathrm{mg} \mathrm{L}^{-1}\right)\end{array}$ & Sulfate $\left(\mathrm{mg} \mathrm{L}^{-1}\right)$ \\
\hline Excellent & $\mathrm{C}_{1}$ & $0-1$ & 5 & 500 & 1.5 & 75 & 150 & 150 \\
\hline Acceptable & $\mathrm{C}_{2}$ & $1-2$ & 10 & 1500 & 3 & 150 & 250 & 250 \\
\hline Slightly polluted & $\mathrm{C}_{3}$ & $2-4$ & 100 & 2100 & 6 & 300 & 600 & 400 \\
\hline Polluted & $\mathrm{C}_{4}$ & $4-8$ & 250 & 3000 & 12 & 500 & 800 & 1000 \\
\hline Heavily polluted & $\mathrm{C}_{5}$ & $8-16$ & $>250$ & $>3000$ & 24 & $>500$ & $>800$ & $>1000$ \\
\hline
\end{tabular}




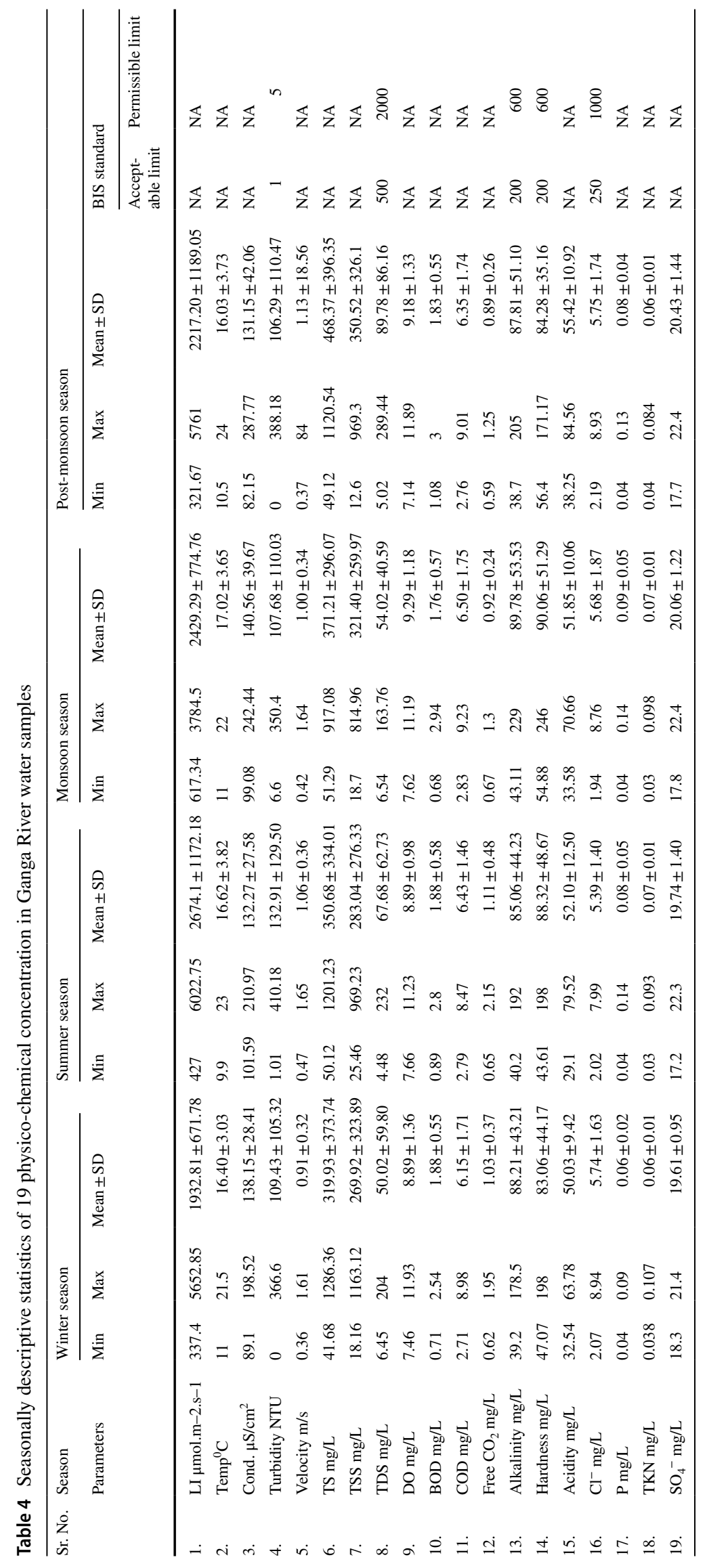


season, respectively. Total dissolved solid (TDS), which is a proportion of the level of value, changes from 60 to $192.6 \mathrm{mg} / \mathrm{L}$, with a mean of $103.56 \mathrm{mg} / \mathrm{L}$ (Bhardwaj et al. 2010).

Dissolved oxygen (DO) plays an important role in the oceanic biological system and to assess the level of freshness of surface water. It also helps to evaluate the quality and natural contamination in the surface water (Wetzel and Likens 2006). For this study the average dissolved oxygen concentration of surface water was noticed $8.89 \pm 1.36$, $8.89 \pm 0.98,9.29 \pm 1.18$ and $9.18 \pm 1.33 \mathrm{mg} / \mathrm{L}$ in winter, summer, monsoon and post-monsoon season, respectively. The total suspended solids were recorded $269.92 \pm 323.89$, $283.04 \pm 276.33,321.40 \pm 259.97$ and $350.52 \pm 326.1 \mathrm{mg} / \mathrm{L}$ during winter, summer, monsoon and post-monsoon season, respectively. Similarly, Rani et al. (2014) observed the TSS variation within the limit of 100-190 mg/L while observing the quality of Ganga Canal water during Kanwar Mela at Haridwar. High amount of TSS may be due to suspension of clay and soil particles (Daphne et al. 2011).

The average biological oxygen demand of all seasons was recorded $1.88 \pm 0.55,1.88 \pm 0.58,1.76 \pm 0.57$ and $1.83 \pm 0.55 \mathrm{mg} / \mathrm{L}$ for winter, summer, monsoon and postmonsoon season, respectively. Aenab (2013) observed that the BOD $(6.5 \mathrm{mg} / \mathrm{L})$ value was out of the WHO standard limit. The average concentration of chemical oxygen demand (COD) was evaluated $6.15 \pm 1.71,6.43 \pm 1.46,6.50 \pm 1.75$ and $6.35 \pm 1.74 \mathrm{mg} / \mathrm{L}$ for winter, summer, monsoon and post-monsoon season, respectively. The seasonally average free $\mathrm{CO} 2$ of surface water was recorded $1.03 \pm 0.37 \mathrm{mg} / \mathrm{L}$, $1.11 \pm 0.48,0.92 \pm 0.24$ and $0.89 \pm 0.26 \mathrm{mg} / \mathrm{L}$ for winter, summer, monsoon and post-monsoon season, respectively. Joshi et al. (2009) reported the COD range between 4.58 and $13.72 \mathrm{mg} / \mathrm{L}$ and free carbon dioxide in the River Ganga was perpetually present consistently. The seasonally average value of total hardness was recorded $83.06 \pm 44.17$, $88.32 \pm 48.67,90.06 \pm 51.29$ and $84.28 \pm 35.16 \mathrm{mg} / \mathrm{L}$ during winter, summer, monsoon and post-monsoon season, respectively. The hardness represents the usability of water for drinking, industrial and domestic purposes.

Concentration of Alkalinity in water is the assurance of the ability to deactivate a solid corrosive. The bases, for instance, hydroxides, bicarbonates, phosphates, nitrates, carbonates, borates, silicates, etc., are in charge of alkalinity of water. It provides a thought of characteristic salts in water (Sharmila and Rajeswari 2015). The seasonally average value of alkalinity was recorded $88.21 \pm 43.21,85.06 \pm 44.23$ $89.78 \pm 53.53$ and $87.81 \pm 51.10 \mathrm{mg} / \mathrm{L}$ for winter, summer, monsoon and post-monsoon season, respectively. Acidity is vital parameter to evaluate the water quality. Dissolved $\mathrm{CO}_{2}$ is the important and main factor which is responsible for acidity in unpolluted water. In this study the seasonally average value of acidity was recorded $50.03 \pm 9.42$,
$52.10 \pm 12.50,51.85 \pm 10.06$ and $55.42 \pm 10 \mathrm{mg} / \mathrm{L}$ during winter, summer, monsoon and post-monsoon season, respectively.

Use of detergents may escalation the phosphate concentration in water to great extent. The man-made additions of phosphorus to the surface water have a considerable impact on the quality of the river water. Such phosphorus is determined for the most part from domestic sewage and the overflow from rural territories. During the study the phosphorus content was also recorded $0.06 \pm 0.02,0.08 \pm 0.05$, $0.09 \pm 0.05$ and $0.08 \pm 0.04 \mathrm{mg} / \mathrm{L}$ in winter, summer, monsoon and post-monsoon season, respectively. A very slight variation in average concentration of $\mathrm{Cl}^{-}$was found as $5.74 \pm 1.63,5.39 \pm 1.40,5.68 \pm 1.87$ and $5.75 \pm 1.74 \mathrm{mg} / \mathrm{L}$ during the study period. The ingestion of water containing higher dose of $\mathrm{Cl}^{-}$can cause hypertension, osteoporosis, rental stones and asthma (McCarthy 2004). The phosphate concentration has positively impact on photosynthetic activities and chlorophyll- $a$ content of aquatic flora, whereas the TKN concentration negatively affect the chlorophyll- $a$ pigment (Tare et al. 2003). The average concentration of $P$ was ranged from $0.06 \pm 0.02 \mathrm{mg} / \mathrm{L}$ in winter to $0.09 \pm 0.05 \mathrm{mg} / \mathrm{L}$ in monsoon season and the mean level of TKN was varied from $0.06 \pm 0.01 \mathrm{mg} / \mathrm{L}$ during winters to $0.07 \pm 0.01 \mathrm{mg} / \mathrm{l}$ during monsoon season. The concentration of $\mathrm{SO}_{4}{ }^{-}$was also reported with a slight variation from $19.61 \pm 0.95$, $19.74 \pm 1.40,20.06 \pm 1.22$ and $20.43 \pm 1.44 \mathrm{mg} / \mathrm{L}$ during winter, summer, monsoon and post-monsoon season, respectively.

\section{Multivariate statistical analysis}

The variability of original average dataset was presented by screen plot (Fig. 2) which show that the first Six components, contributes for $80.3 \%$. Therefore, the details about the water quality at different 20 sites can be performed in reduced data set of six variables. On the basis of Eigen value criteria, six principal components (PCs) were noticed important as their eigenvalues are greater than one. Now the number of clusters can be selected according to the reported number of principle components to categorize the sampling sites. In this study, it is observed from screen plot that only six clusters are necessary to group the monitoring sites.

The factor weights values of observed factors related to each principle components are represented in Table 5. The PCs are classified as 'weak', 'moderate' and 'strong' on the basis of their factor loading values $(>0.75,0.75-0.50$ and 0.50-0.30, respectively) (Liun et al. 2003). It was determined that the variables turbidity, $\mathrm{BOD}$, free $\mathrm{CO}_{2}$ had a negative factor weight, $-0.357,-0.335$ and -0.328 , respectively in the development of PC1 with $24.9 \%$ of variation. This component indicates organic source of pollution from natural processes and agro-based industries (Sharma et al. 
Fig. 2 Screen plot of various PCs

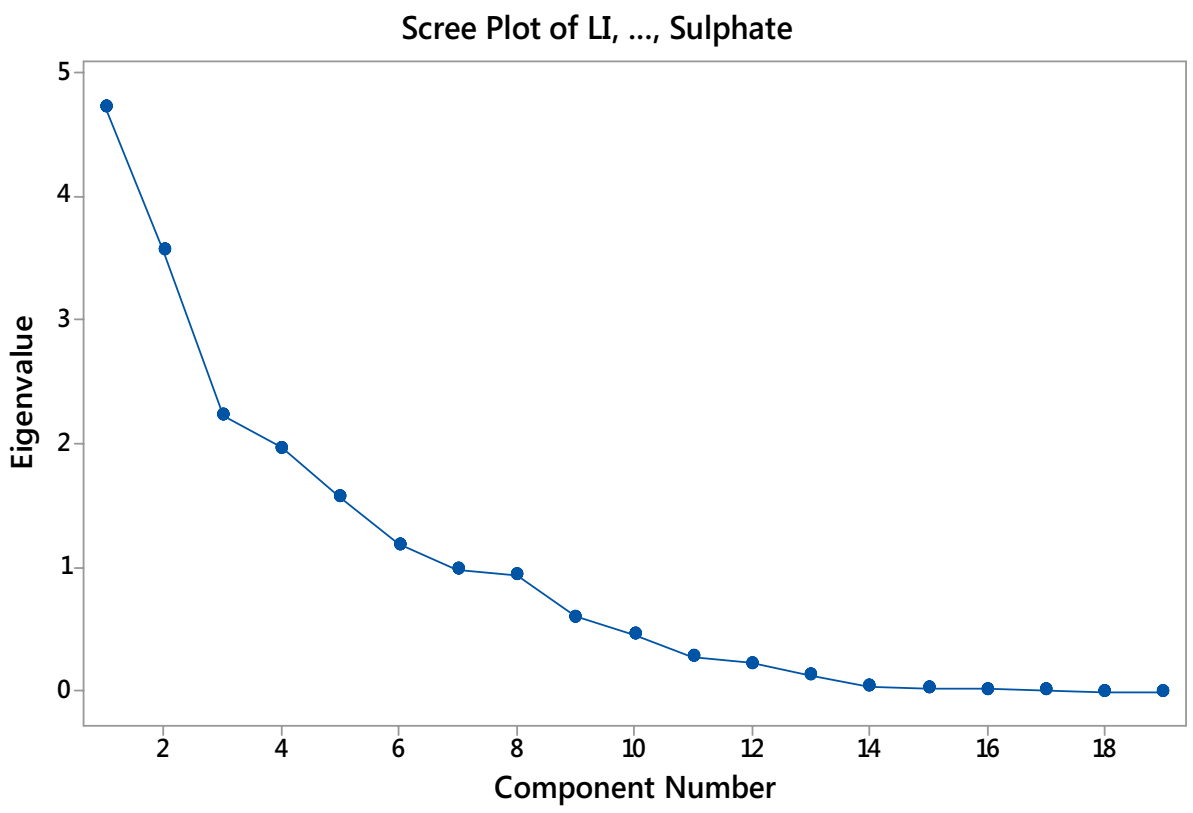

Table 5 Principal component loadings (Varimax normalized) for the physico-chemical parameters of the Ganga River water

\begin{tabular}{|c|c|c|c|c|c|c|c|}
\hline \multirow[t]{2}{*}{ Sr. No. } & \multirow[t]{2}{*}{ Variables } & \multicolumn{6}{|c|}{ Components } \\
\hline & & $\mathrm{PC} 1$ & $\mathrm{PC} 2$ & PC3 & PC4 & PC5 & PC6 \\
\hline 1. & LI $\mu$ mol.m-2.s-1 & 0.197 & 0.072 & 0.100 & -0.401 & -0.050 & -0.300 \\
\hline 2. & Temp ${ }^{\circ} \mathrm{C}$ & 0.147 & 0.238 & 0.085 & 0.107 & 0.451 & -0.124 \\
\hline 3. & Cond. $\mu \mathrm{S} / \mathrm{cm}^{2}$ & -0.224 & -0.117 & 0.056 & 0.333 & -0.202 & -0.177 \\
\hline 4. & Turbidity NTU & -0.357 & 0.238 & 0.118 & 0.011 & -0.024 & -0.013 \\
\hline 5. & Velocity $\mathrm{m} / \mathrm{s}$ & -0.274 & -0.091 & 0.345 & 0.102 & -0.175 & -0.103 \\
\hline 6. & $\mathrm{TS} \mathrm{mg} / \mathrm{L}$ & 0.054 & 0.114 & 0.037 & -0.321 & 0.302 & 0.559 \\
\hline 7. & $\mathrm{TSS} \mathrm{mg} / \mathrm{L}$ & -0.212 & -0.332 & -0.302 & -0.034 & 0.325 & -0.019 \\
\hline 8. & TDS mg/L & -0.231 & -0.333 & -0.263 & 0.008 & 0.337 & 0.044 \\
\hline 9. & DO mg/L & -0.165 & -0.422 & -0.154 & -0.206 & 0.046 & 0.031 \\
\hline 10. & BOD mg/L & -0.335 & 0.038 & 0.198 & -0.017 & -0.177 & 0.318 \\
\hline 11. & COD mg/L & 0.308 & 0.120 & -0.125 & -0.234 & -0.182 & 0.026 \\
\hline 12. & Free $\mathrm{CO}_{2} \mathrm{mg} / \mathrm{L}$ & -0.328 & 0.044 & 0.215 & -0.141 & -0.006 & 0.138 \\
\hline 13. & Alkalinity mg/L & 0.028 & -0.132 & -0.258 & -0.355 & -0.463 & 0.203 \\
\hline 14. & Hardness mg/L & 0.192 & -0.311 & 0.363 & -0.048 & 0.087 & -0.030 \\
\hline 15. & Acidity mg/L & 0.196 & -0.319 & 0.400 & 0.015 & 0.089 & 0.007 \\
\hline 16. & $\mathrm{Cl} \mathrm{mg/L}$ & 0.001 & 0.276 & -0.393 & 0.291 & 0.043 & -0.052 \\
\hline 17. & P mg/L & 0.281 & -0.329 & -0.040 & 0.135 & -0.084 & -0.167 \\
\hline 18. & $\mathrm{TKN} \mathrm{mg} / \mathrm{L}$ & 0.259 & -0.021 & 0.139 & 0.359 & 0.091 & 0.506 \\
\hline \multirow[t]{4}{*}{19.} & Sulfate $\mathrm{mg} / \mathrm{L}$ & -0.149 & 0.170 & 0.165 & -0.353 & 0.312 & -0.296 \\
\hline & Eigen Value & 4.72 & 3.56 & 2.23 & 1.96 & 1.57 & 1.18 \\
\hline & $\%$ of total variation & 24.9 & 18.8 & 11.8 & 10.3 & 8.3 & 6.3 \\
\hline & Cumulative & 24.9 & 43.6 & 55.4 & 65.7 & 74 & 80.3 \\
\hline
\end{tabular}

2015). The PC2 was associated with a negative weight with DO (-0.422) only with $18.8 \%$ variation. The weight of the variables Hardness (0.363) and acidity (0.400) was positive and $\mathrm{Cl}(-0.393)$ had a negative factor weight in the formation of PC3 with $11.8 \%$ variation. Positive weight in PC4 had LI (-0.401), alkalinity (-0.355), TKN (0.359), and
$\mathrm{SO}_{4}^{-}{ }^{-}(-0.353)$ had a negative weight with 10.3 variation. For PC5 the variables temperature $(0.451)$ had positive weight while only alkalinity $(-0.463)$ had a negative weight with $8.3 \%$ variation. The formation of moderate PC6 includes a positive weight with TS (0.559) and TKN (0.506) with total variation of $6.3 \%$. 
The grouping between the similar monitoring sites was detected by CA and presented by a dendrogram in Fig. 3. The dendrogram represents the six groups of monitoring site, in each group all sampling locations without any specific trends. Cluster I is generated by sites 1, 3, 6 and 4, Cluster II of site number 7, 9 and 12, Cluster III by 2, 5 and 11, Cluster IV shows two sites 8 and 10, Cluster V is generated by sites 13, 15, 14 and 16 and the last Cluster VI include 17, 19, 20 and 18. These clusters receive domestic sewage, sewage musk from hydro-electric power plants, effluents from electroplating, automobile and pharmaceutical industries (Sharma et al. 2015).

\section{Indexing approach}

The all values of NSFWQI are given in Table 6, which presents the surface water quality status during the study period was monitored to differ among medium and good range. The average value of NSFWQI for all seasons is introduced in Table 6. Table 6 shows the good water quality at Gangotri and Uttarkashi in winter (NSFWQI: 77 and 75) and summer season (NSFWQI: 84 and 81), while the lowest was drawn at Jatwara Bridge, Haridwar (NSFWQI: 41) in monsoon season (Fig. 4). As to average, the most noticeably worst water quality was found in Monsoon season. During the 1-year study period, depend on quality of surface water index values (Table 6), the quality of water in the monsoon and post-monsoon was average and was good in summer and winter season. At Gangotri, Badrinath, Rudraprayag, Srinagar, Mayapur (Haridwar) and Jatwara Bridge (Haridwar), the quality of River water was acceptable in the summer season, and in other season, the quality was normal, which was the consequence of illegal wastewater release in river. Some other responsible factors, for example, anthropogenic activities, street development, farming activities and different factors unfavorably influence the surface water quality of these sampling locations.

For this study, OIP was additionally used for the assessment of water quality indexing. The seasonally values of OIP of all the sampling sites of selected physico-chemicals parameters is presented in Table 6 . The result shows that the water quality status of Ganga River was in the range class C2 (1-2) acceptable in summer and C3 (2-4) scarcely polluted in winter, Monsoon and post-monsoon season, respectively (Fig. 5). Shukla et al. (2017a) examined the water quality of Upper Ganga River basin using OIP and observed that because of high stream flow, water quality at Uttarkashi was acceptable (class C2: 1-2) from 2001 to 2012, while slightly contaminated (class C3: 2-4) in monsoon period during 2006.

The highest value (C3 class) of OIP was observed in monsoon season with value varied from 2.01 at Trivenighat, Rishikeshto 3.97 at Jatwara Bridge, Haridwar with an mean value of $2.45 \pm 0.713$ (Table 6). During this season, the water quality status of Ganga River was slightly contaminated. This might be because of heavy overflow of water sediments, agricultural runoff and converging of sewage water from various point sources. Different analysts were additionally observed the comparable results of pollution status in monsoon period, for example, Gupta et al. (2017) in Narmada River, Jindal and Sharma (2010) in Sutlej River, Sebastian and Yamakanamardi (2013) in Kapila and Cauvery River.
Fig. 3 Dendrogram of various sampling locations

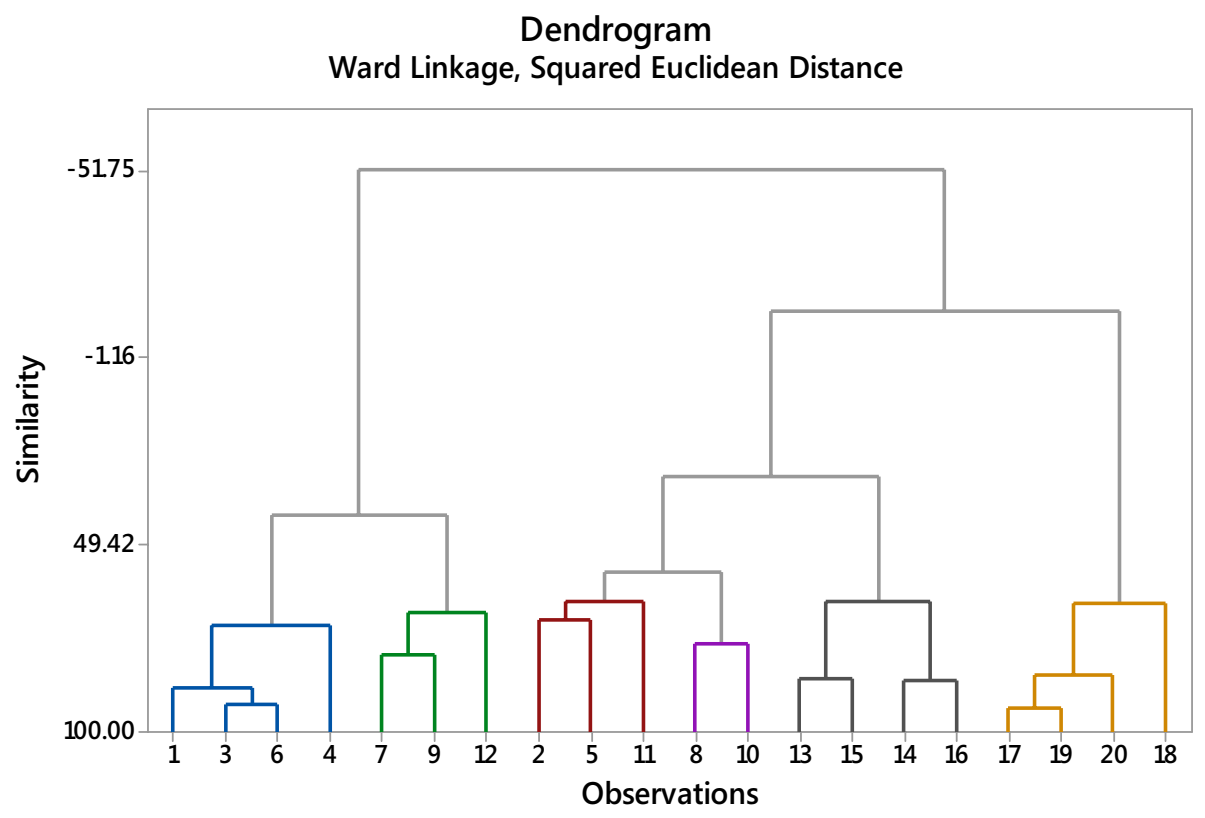




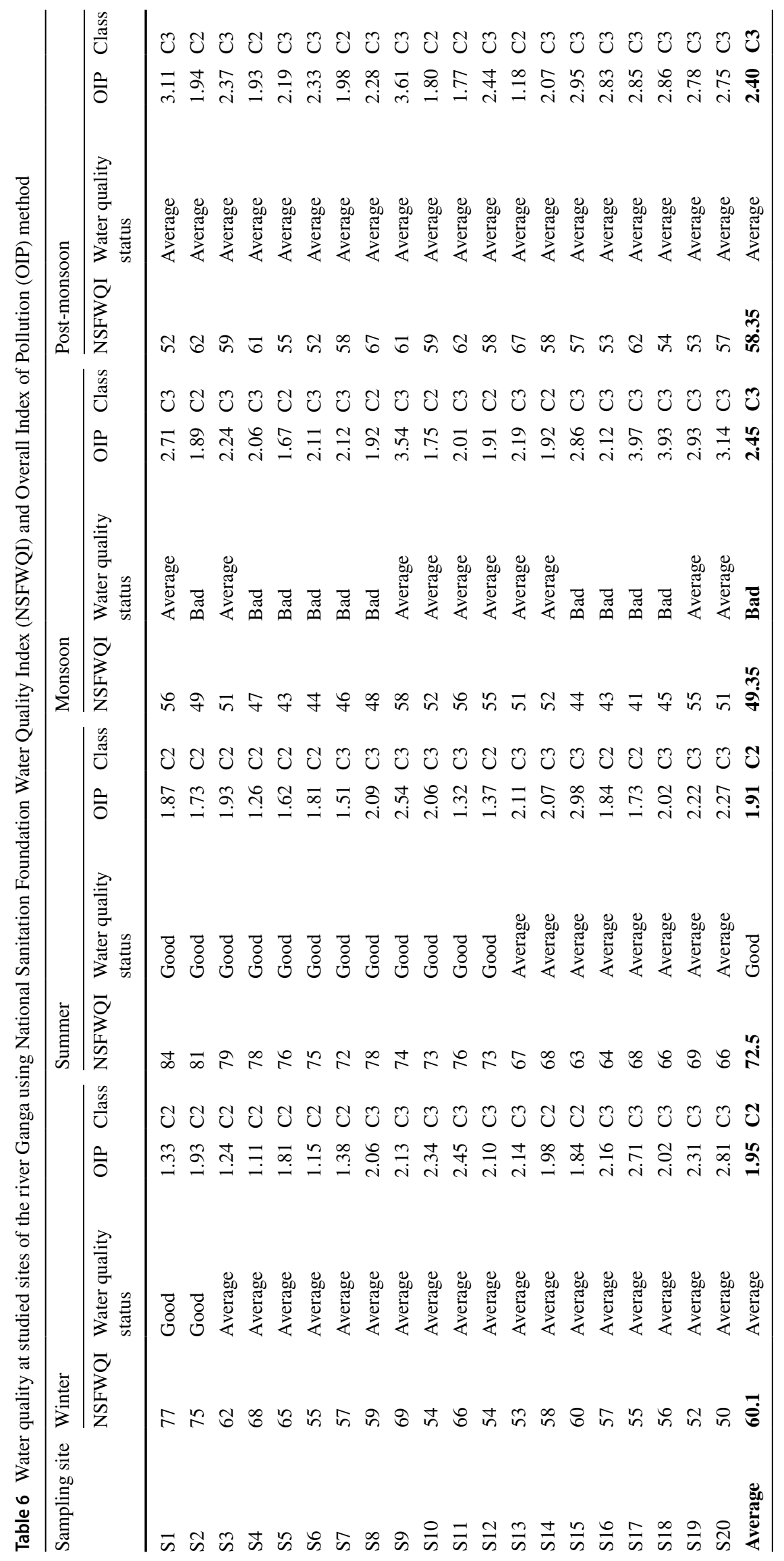


Fig. 4 Seasonal variation in NSFWQI values for each monitoring stations
Fig. 5 Seasonal variation in OIP values for each monitoring stations
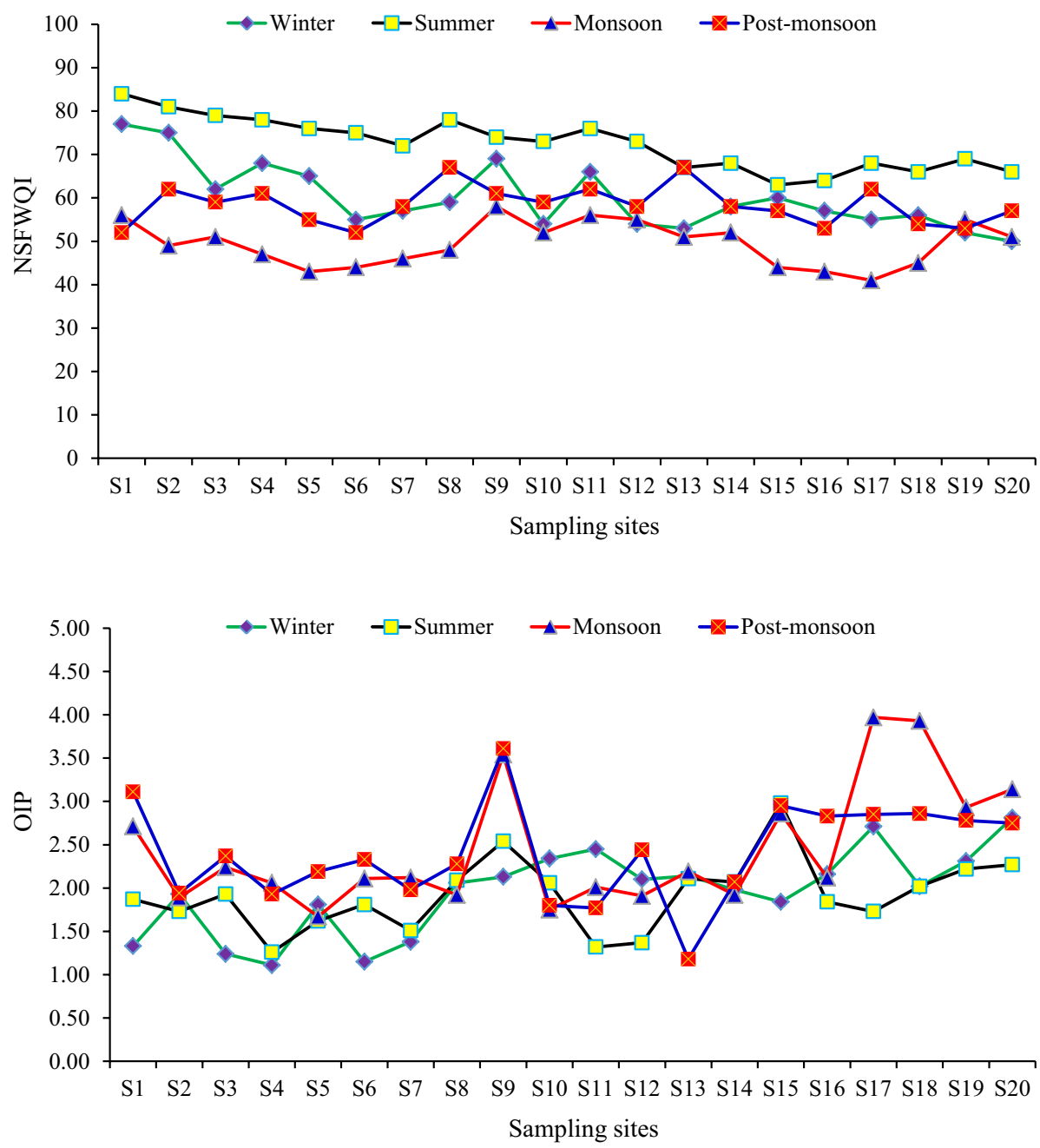

\section{Conclusions}

Based on the results obtained from the present study, the water quality of Ganga River system in Himalayan region of Uttarakhand, India, was vulnerable to pollution during 2015-2016. The higher level of turbidity made the water quality unsuitable for drinking purposes, while compared to the Indian standards. The WQI and multivariate statistical models were proved to be beneficial approaches to classify the spatial and temporal variation in river water quality, by transforming the dataset into commensurate unit data and numeric index values. NSFWQI and OIP elicit the water quality in good or acceptable class for upstream sites (Gangotri and Uttarkashi) during winter and summer season, whereas slightly pollution was reported for downstream site (Jatwara Bridge, Haridwar) during monsoon season. The PCA analysis elucidates the relationship among important parameters by reducing number in the form of PCs and their contribution in variation. It also helps in pollution source identifications.
There were six components recognized that can attribute to organic pollution (agricultural waste), rainfall runoff and riverbed erosion. According to CA, similar pollution causing monitoring stations were grouped into six clusters. The CA findings will help to reduce the number of sampling stations and the sampling expanses for further assessment. These findings essentially provide information on river water quality management and pollution control measures.

Acknowledgements The work space and instrumentation for the current manuscript was supported by Department of Zoology and Environmental Science, Gurukul Kangri Vishvidalaya, Haridwar (India).

\section{Compliance with ethical standards}

Conflict of interest The authors announce that there is no conflict of interest with respect to the distribution of this manuscript.

Open Access This article is licensed under a Creative Commons Attribution 4.0 International License, which permits use, sharing, adaptation, distribution and reproduction in any medium or format, as long as you give appropriate credit to the original author(s) and the source, provide a link to the Creative Commons licence, and indicate if changes 
were made. The images or other third party material in this article are included in the article's Creative Commons licence, unless indicated otherwise in a credit line to the material. If material is not included in the article's Creative Commons licence and your intended use is not permitted by statutory regulation or exceeds the permitted use, you will need to obtain permission directly from the copyright holder. To view a copy of this licence, visit http://creativecommons.org/licenses/by/4.0/.

\section{References}

Abbasi T, Abbasi SA (2012) Water quality indices. Elsevier, Amsterdam, p 384

Aenab AM (2013) Evaluating water quality of Ganga canal within Uttar Pradesh state by water quality index analysis using $\mathrm{C}++$ Program. Civil Environ Res 3:57-65

Alobaidy AHMJ, Abid HS, Maulood BK (2010) Application of water quality index for assessment of Dokan lake ecosystem, Iraq. J Water Res Prot 2:792-798

American Public Health Association (APHA) (2012) Standard Methods for examination of water and wastewater. 22nd ed. Washington $1360 \mathrm{pp}$. ISBN 978-087553-013-0

Awasthi N, Ray E, Paul D (2018) Sr and Nd isotope compositions of alluvial sediments from the Ganga Basin and their use as potential proxies for source identification and apportionment. Chem Geol 476:327-339

Barakat A, Baghdadi ME, Rais J, Aghezzaf B, Slassi MM (2016) Assessment of spatial and seasonal water quality variation of OumErRbia river (Morocco) using multivariate statistical techniques. Int Soil Water Conserv Res. https://doi.org/10.1016/j. iswer.2016.11.002

Bhardwaj RM (2005) Water quality monitoring in India-achievements and constraints. IWG-Env, International Work Session on Water Statistics, Vienna, June 20-22 2005

Bhardwaj V, Singh DS, Singh AK (2010) Water quality of the ChhotiGandak Canal using principle component analysis, Ganga Plan, India. Ind J Earth Syst Sci 119:117-127

Bharti N, Katyal D (2011) Water quality indices used for surface water vulnerability assessment. Int J Ecol Environ Sci 2(1):154-173

Brown RM, McClelland NI, Deininger RA, Tozer RG (1970) Water quality index-do we dare? Water Sew Works 117(10):339-343

Bureau of Indian Standards (BIS) (2012) Indian standard specification for drinking water, 10500. New Delhi, India

Census of India (2011) Uttarakhand Profile. Censusinfo India 2011: Final Population Total. https://censusindia.gov.in/2011census /censusinfodashboard/stock/profiles/en/IND005_Uttarakhan d.pdf. Accessed 2 July 2020

Chakrapani GJ, Saini RK (2009) Temporal and spatial variations in water discharge and sediment load in the Alaknanda and Bhagirathi Rivers in Himalaya, India. J Asian Earth Sci 35:545-553. https://doi.org/10.1016/j.jseaes.2009.04.002

Chauhan M (2010) A perspective on watershed development in the Central Himalayan state of Uttarakhand, India. Int J Ecol Environ Sci 36(4):253-269

CWC (2012) Environmental evaluation study of Ramganga major irrigation project. Central Water Commission 1:16

Daphne LHX, Utoma HD, Kenneth LZH (2011) Correlation between turbidity and total suspended solids in Singapore canals. J Water Sust 1:313-322

Fan X, Cui B, Zhao H et al (2010) Assessment of river water quality in Pearl river Delt using multivariate statistical techniques. Procedia Environ Sci 2:1220-1234

Gupta N, Pandey P, Hussain J (2017) Effect of physicochemical and biological parameters on the production \& manufacturing research 73 quality of river water of Narmada, Madhya Pradesh, India. Water Sci 31:11-23. https://doi.org/10.1016/j. wsj.2017.03.002

Jindal R, Sharma C (2010) Studies on water quality of Sutlej river around Ludhiana with reference to physicochemical parameters. Environ Monit Assess 174:417-425. https://doi.org/10.1007/ s10661-010-1466-8

Joshi DM, Kumar A, Agarwal N (2009) Studies on physcochemical parameters to assess the water quality of canal Ganga for drinking purpose in Haridwar district. Rasayan J Chem 2(1):195-203

Kaushal N, Babu S, Mishra A, Ghosh N, Tare V, Kumar R, Sinha PK, Verma RU (2019) Towards a healthy ganga-improving river flows through understanding trade offs. Front Environ Sci 7:83. https://doi.org/10.3389/fenvs.2019.00083

Kumar A, Sanyal P, Agrawal S (2019) Spatial distribution of $\delta 180$ values of water in the Ganga River basin: insight into the hydrological processes. J Hydrol (Amst.) 571:225-234

Liun CW, Linn KH, Kuon YM (2003) Application of factor analysis in the assessment of groundwater quality in a black foot disease area in Taiwan. Sci Total Environ 313(1-3):77-89

Lumb A, Sharma TC, Bibeault JF (2011) A review of genesis and evolution of water quality index (WQI) directions. Water Qual Expo Health 3:11-24

Lupker M, France-Lanord C, Galy V, Lavé J, Gaillardet J, Gajurel AP, Sinha R (2012) Predominant floodplain over mountain weathering of Himalayan sediments (Ganga basin). Geochim Cosmochim Acta 84:410-432

Madhuben Sharma, Ankur Kansal, Suresh Jain, Prateek Sharma (2015) Application of multivariate statistical techniques in determining the spatial temporal water quality variation of Ganga and Yamuna Rivers rresent in Uttarakhand state, India. Water Qual Expo Health 7:567-581. https://doi.org/10.1007/ s12403-015-0173-7

Massoud MA (2012) Assessment of water quality along a recreational section of the Damour river in Lebanon using the water quality index. Environ Monit Assess 184:4151-4160

Mathur RP, Kapoor V (2015) Concept of keystone species and assessment of flows (Himalayan segment-Ganga river). In: Int. conf. hydropower sustain. dev. pp 387-397

Matta G, Uniyal DP (2017) Assessment of species diversity and impact of pollution on limnological conditions of river Ganga. Int J Water 11(2):87-102

Matta G, Srivastava S, Pandey RR, Saini KK (2015) Assessment of physicochemical characteristics of Ganga Canal water quality in Uttarakhand. Environ Dev Sustain. https://doi.org/10.1007/s1066 8-015-9735-x

Matta G, Naik PK, Machell J, Kumar A, Gjyli L, Tiwari AK, Kumar A (2018a) Comparative study on seasonal variation in hydro-chemical parameters of Ganga River water using comprehensive pollution index (CPI) at Rishikesh, (Uttarakhand) India. Desalination Water Treat. https://doi.org/10.5004/dwt.2018.22487

Matta G, Kumar A, Tiwari AK, Naik PK, Berndtsson R (2018b) HPI appraisal of concentrations of heavy metals in dynamic and static flow of Ganga River System. Environ Develop Sustain. https ://doi.org/10.1007/s10668-018-01182-3 ISSN: 1387-585X; EISSN: 1573-2975

Matta G, Kumar A, Naik PK, Tiwari AK, Bendtsson R (2018c) Ecological analysis of nutrient dynamics and phytoplankton assemblage in the Ganga River system, Uttarakhand. Taiwan Water Conserv 66(1):1-12

Matta G, Kumar A, Nayak A, Kumar P, Kumar A, Tiwari AK (2020) Water quality and planktonic composition of river Henwal (India) using comprehensive pollution index and biotic-indices. Trans Indian National Acad Eng. https://doi.org/10.1007/s4140 3-020-00094-x 
McCarthy MF (2004) Should we restrict chloride rather than sodium? Med Hypotheses 63(1):138-148

Misaghi F, Delgosha F, Razzaghmanesh M, Myers B (2017) Introducing a water quality index for assessing water for irrigation purposes: a case study of the GhezelOzan River. Sci Total Environ 589:107-116

NMCG (National Mission for Clean Ganga) (2019) GRBMP reports. Ganga basin plan report 1. River Ganga at a glance: identification of issues and priority actions for restoration. https://nmcg.nic.in/ writereaddata/fileupload/33_43_001_GEN_DAT_01.pdf

Noori R, Abdoli MA, Jalili GM (2009) Comparison of neural network and principal component-regression analysis to predict the solid waste generation in Tehran, Iran. J Public Health 38:74-84 (In Persian)

Noori R, Khakpour A, Omidvar B (2010) Comparison of ANN and principal component analysis-multivariate linear regression models for predicting the river flow based on developed discrepancyratio statistic. Expert Syst Appl 37:5856-5862 (In Persian)

Ouyang Y (2005) Evaluation of river water quality monitoring stations by principal component analysis. Water Res 39:2621-2635

Rana RS, Singh P, Kandari V, Singh R, Dobhal R, Gupta S (2017) A review on characterization and bioremediation of pharmaceutical industries' wastewater: an Indian perspective. Appl Water Sci. $7: 1-12$

Rani P, Tiwari A, Navin R, Shivani S (2014) Studies in determination of some parameters of 'Ganga river water, KanwarMela 2013, Haridwar. J Innovative Biol 1(2):122-125

Sadiq R, Haji SA, Cool G, Rodriguez MJ (2010) Using penalty functions to evaluate aggregation models for environmental indices. $\mathrm{J}$ Environ Manage 91(3):706-716

Saeid Hazrati, Zeinolabedin Tahmasebi-Sarvestani, Mohammad Modarres-Sanavy Seyed Ali, Ali Mokhtassi-Bidgoli, Silvana Nicola (2016) Effects of water stress and light intensity on chlorophyll fluorescence parameters and pigments of Aloe vera L. Plant Physiol Biochem 106:141-148. https://doi.org/10.1016/j. plaphy.2016.04.046

Sargaonkar A, Deshpande V (2003) Development of an overall index of pollution for surface water based on a general classification scheme in Indian context. Environ Monit Assess 89:43-67

Sebastian KJ, Yamakanamardi SM (2013) Assessment of water quality index of Cauvery and Kapila river and their confluence. Int $\mathrm{J}$ Lakes Rivers 1:59-67

Shah KA, Joshi GS (2017) Evaluation of water quality index for River Sabarmati, Gujarat, India. Appl Water Sci 7:1349-1358. https:// doi.org/10.1007/s13201-015-0318-7
Sharmila J, Rajeswari R (2015) A study on physico-chemical characteristics of selected ground water samples of Chennai city, Tamil Nadu. IJIRSET 4(1):95-100

Shrestha S, Kazama F (2007) Assessment of surface water quality using multivariate statistical techniques: a case study of the Fuji river basin, Japan. J Environ Model Softw 22:464-475

Shukla AK, Ojha CSP, Garg RD (2017a) Application of overall index of pollution (OIP) for the assessment of the surface water quality in the upper Ganga river basin, India. Water Sci Technol Library. https://doi.org/10.1007/978-3-319-55125-8_12

Shukla AK, Ojha CSP, Garg RD (2017b) Surface water quality assessment of Ganga River Basin, India using index mapping. In: IEEE International Geoscience and Remote Sensing Symposium (IGARSS), Fort Worth, TX, 2017, pp 5609-5612

Tare Vinod, Roy Gautam, Bose Purnendu (2013) Ganga river basin environment management plan: interim report: IIT Consortium: August 2013. http://mowr.gov.in/sites/default/files/GRBEMPInte rimReport_2.pdf. Accessed 2 July 2020

Tare Vinod, Roy Gautam, Bose Purnendu (2015) Ganga river basin management plan: extended summary. http://cganga.org/wp-conte nt/uploads/sites/3/2018/11/GRBMP-Extended-Summary_March 2015.pdf

Tare V, Yadav ASV, Purnendu Bose (2003) Analysis of photosynthetic activity in the most polluted stretch of river Ganga. Water Res 37:67-77

TERI (2017) Study of assessment of water foot prints of India's long term energy scenarios New Delhi: the energy and resources institute. [Project Report No. 2015WM07]

Truong Son Cao, Huong Giang Nguyen Thị, Phuong Thao Trieu, Hai Nui Nguyen, Thanh Lam Nguyen, Huu Cong Vo (2020) Assessment of Cau River water quality assessment using a combination of water quality and pollution indices. J Water Supply Res Technol Aqua 69(2):160-172. https://doi.org/10.2166/aqua.2020.122

Wetzel RG, Likens GE (2006) Limnological analysis, vol 391, 3rd edn. Springer, New York

Publisher's Note Springer Nature remains neutral with regard to jurisdictional claims in published maps and institutional affiliations. 